\title{
海上とシミュレー夕に扩ける距離感㧍よび その教示効果について
}

馬谷 正樹*・河口 信義*

\section{On Distance Cognition and It's Learning Effect on the Sea and Bridge Simulator}

\author{
Masaki UMATANI and Nobuyoshi KOHGUCHI
}

\begin{abstract}
In recent years, various kinds of maritime simulator have been set up to education, training and research organizations, and they are took the advantage in various fields of the maritime education, training and research. Also at present the possibility to substitute the embarkation career as a seafarer for the maritime simulator training are examined. However from the viewpoint of ergonomics and human information processing, there are many problems that should be solved, before the cadet who have a little career as a seafarer are trained by means of the virtual reality system called the maritime visual simulator. For example, how should trainee has an experience of ship's maneuvering and which degree or how should trainee get the cognitive distance to another ship?

If we could investigate and solve those problems, the simulator training and training on board become more effective for the seafarer. When navigator maneuvers the vessel, he needs much information through his five senses. In the five senses the sight of sense has $80 \%$ of all information, besides in the sight of sense it is said that the "distance" information is the most important things in the judgment standard of risk of collision. In this paper, we describe the experimental results of two cognitive distances, one distance was took from the simulator experiment and the other from the real ship experiment on the sea.

At last, we recommend that trainee should have the correct cognitive distance before maritime simulator training and for the safety of navigation it is necessary that navigator recognize the correct distance to another ship by means of Radar. and as a result of consideration we show the following things ;

(1) When the trainee's height of eye is not different from his usual height of eye on board and the trainee has a lot of embarkation career as a able seaman, the visual simulator is regarded as a most effective and valuable training instrument.

(2) When the trainee's height of eye is different from his usual height of eye on board, it is attention that the trainee's cognitive distance has influence of the experimental and memorized distance, become incorrect.

(3) The seafarer's cognitive distance from own ship to another ship has an influence of the angle between a horizontal line and a waterline of another ship.

(4) The instruction of distance is effective to be correct cognitive distance for any trainee in simulator.
\end{abstract}

* 正会員 神戸商船大学（广658-0022 神戸市東灘区深江南町5-1-1） 


\section{1.はじめに}

近年、教育訓練機関や研究機関に各種シミュレー 夕が導入され、様々な分野でその利点を生かし教育 研究に用いられている。また、船員の海上乗船履歴 をシミュレータ訓練で代替する可能性も検討されて いる(1)。しかしながら、シミュレー夕を用いた研究で の被験者や訓練生の多くは乗船経験者である。また、 乗船経験年数の少ない学生を対象として訓練回数に 対する要素技術と複合技能レベルの変化を示した研 究(2)があるが、実験における被験者の数も少なく乗 船経験が異なることでどのような違いがあるのかは 示されていない。

海、船という現場をあまり知らない学生をシミュ レータという仮想現実の中で訓練させるには、操船 者の情報の収集と処理の観点から多くの解決すべき 問題点があると考えられる。例えば、自船の操縦性 能をどの程度まで習熟させておくべきか、あるいは 他船までの距離感をどのように教示すべきかなどで ある。

そこで、これらの問題点を見つけ出し、解決する ことによって、はじめてシミュレータによる実習と 海上における乗船実習がお互いの利点と欠点を補い 合い、教育訓練効果の更なる向上が期待できるもの と考える。

操船者が航海中に得る視覚情報の中で、衝突の可 能性など航行の安全性を判断する基準として、最も 重要と考えられているのは他船までの「距離」情報

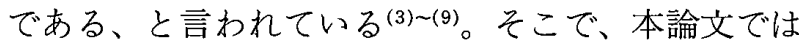
この距離情報に着目し、視覚からの距離知覚および 認知がシミュレータと実際の船（海上実験）との間 でどの程度異なるか、またシミュレータによる距離 情報の教示を行った場合、その距離感にどの程度の 違いがあるかについて実験を行った。

\section{2. 距離感}

\section{1 距離感とは}

目に光を与えると見え、感覚器が刺激によって反 応して生ずる意識を感覚という。感覚系は、単に刺 激の強さや波長などに感ずるだけでなく、いろいろ の事物を検出する。視覚は物体の形や大きさ、物体 の運動、その存在する空間的な距離などを知る。こ のような働きは知覚と呼ばれる。知覚は感覚よりも より高次の働きで、総合的、客観的な判断内容をもっ ている。さらに知覚された事物はなんであるか概念 や意味を汲み取り、知識とする働きを持っている。 この働きは認知と呼ばれている。認知を行うために
は、既に経験や学習によって知識として記憶してい る内容と照合することが必要である。ここで感覚器 に入る情報が上位に向かって処理される過程をデー 夕推進形処理といい、一方記憶内容が下位におりて くる過程を概念推進形処理という。我々の認知過程 は、このボトムアップとトップダウンのドッキング によると考えられている(10)。

そこで、このような距離の認知過程においてこの ボトムアップとトップダウンのドッキングによって 得られたものを「認知距離」と呼び、「視覚によって 知覚した経験に基づく記憶や、学習に基づいて認知 した自船から対象船舶までの距離」と定義し、単な る物体の大きさ形から得られたものを「知覚距離」 と呼び、視覚によって知覚した自船から対象船舶ま での距離」と定義する。また、これら認知、知覚距 離の両方を総称して「距離感」と呼ぶ(11)(12)。

\section{2 両眼性と単眼性}

視覚から距離を判断する要因として、両眼性の現 象と単眼性の現象に分けられる。両眼性のものには 再眼視差が挙げられるが、これは通常 $20 \mathrm{~m}$ 以内の距 離で有効であることが知られている(13)。よって今回 のような海上での見張りにおける距離判断は単眼性 の現象であると考えられる。海上において対象船舶 までの距離を判断するに当たって、判断を可能にす る手掛かりが必要である。単眼性の手掛かりは外界 を見て経験的に会得されるものである。このことか ら、操船者として経験豊富な被験者とそうではない 被験者とを比較した場合、経験豊富な被験者は常時 見張りにおいて自分の距離感とレーダから得られる 距離情報を比較していることから、判断された距離 は認知距離であると考えられ、その結果かなり正し い值を示すものと考えられる。また、経験豊富では ない被験者の距離判断は認知距離よりも知覚距離に 近いと考えられ、経験豊富な被験者と比べて正確で は無い距離判断を行うと考えられる。しかしながら、 距離判断が正確でない被験者であっても距離の教示 を行うことで対象船舶までの距離を学習した場合、 程度の差はあるが学習の効果が現れると考えられ る。

\section{3 単眼性認知距離の手掛かり}

周囲に水平線しか見えない環境で1隻の対象船舶 までの距離を、操船者はどのようにして把握してい るのであろうか。これについては以下のように考之 られる(14)。

1 . 水平線からの俯角による

網膜上の視覚が同じ船舶であっても水平線上 に存在する船船と、水平線より下に船船の喫 
水線がある船船と比較をすると、水平線より 下に䝟水線がある船舶の方が近距離に存在 し、水平線上に喫水線が存在する船舶は遠方 に存在し、遠方の船船の方が大きく感じられ る。この位置の遠近関係は船舶の大きさから 判断するのではなく、水平線と喫水線の位置 関係が明瞭になっているので距離感を把握で きる。

2. 対象物の大きさによる

至近に存在する小型船は網膜にはかなり大き く映る。網膜の映像が大きくても、これは近 距離㲹存在するから大きく映るのは当然であ ると判断される。この場合に、遠方に存在す る大型タンカーが網膜上で漁船と同じ大きさ に映ったとしても、大型タンカーは遠距離に 存在するから網膜には小さく映るのが当然で あると意識され、漁船は小さく、大型タンカー は大きいと感じる。視覚が同じ大きさである 場合には遠方にあると認められる船舶ほど大 きいと感じる。一方もし実際の大きさが同じ であれば、遠方の船舶ほど視覚が小さい。し たがって遠方の船舶ほど小さく見えることに なる。しかも遠方に行けば小さく見えるのが 当然であるとの判断が働いて、船舶そのもの が小さいのではないと理解される。これは「大 きさの恒常性」と呼ばれる現象でありこのこ とから距離感を把握できる。

3．色の明るさおよび濃淡による

大気の影響を受け、遠方の物体ほど実際の色 とは異なり、遠くになるほど色が淡くなって いく。このことから距離感を把握できる。

4. 海面状況（テクスチャー）による

波のきめの細かい部分を奥の方に、きめの粗 い部分を近くに感じることから距離感を把握 できる。特に、シミュレータのスクリーン上 に表示される海面のテクスチャーにより、距 離に関する情報を与えることが考えられる。 これらのことから距離感を把握できるが、正確な 距離が分かるわけではない。両眼視の場合は練習に よって距離の目測がかなり正確になることが多い が、単眼視の場合は比較するものが無い場合には正 確な目測は不可能であるとされている。しかし、海 上の操船者は上述のように様々な比較対象物によっ て比較的正確に距離を何海里と把握しているものと 考えられる。

\section{3 . 実験概要}

\section{1 実験装置および設定状況}

海上実験は本学練習船「深江丸」で実施し、シミュ レータ実験は模擬船橋とビジュアルシステムを備え た神戸商船大学のレーダー航法実験研究装置を用い て実施した。レーダ一航法実験研究装置の概要と設 定状況を表 1、2 に示す。

\section{表 1 実験装置の概要}

\begin{tabular}{|c|c|}
\hline 製造者 & Kongsberg Norcontrol \\
\hline 水平視野角 & $210[\mathrm{deg}]$ \\
\hline スクリーン距離 & $7[\mathrm{~m}]$ \\
\hline 投影方法 & プロジェクター方式 $^{\prime}$ \\
\hline 分解能 (水平×垂直) & $1.8^{\prime} \times 1.8^{\prime}$ \\
\hline
\end{tabular}

表 2 実験の設定条件

\begin{tabular}{|c|c|}
\hline 実験海域 & 外洋 (水平線のみ視認できる海域) \\
\hline 視界 & 良好 $(40$ 海里 $]$ に設定 $)$ \\
\hline 波高 & $0[\mathrm{~m}]$ \\
\hline 天気 & 晴れ \\
\hline 海面波テクスチャ & 有り \\
\hline 船首部映像 & 非表示 \\
\hline 自船船速 & $0[\mathrm{knot}]$ \\
\hline
\end{tabular}

\section{2 実験方法}

\section{2 .1 海上実験}

海上実験は本学練習船「深江丸」の平成 12 年 3 月 7 日から 10 日までの春季研究航海において、大阪湾 及び瀬戸内海を航行中の練習船船橋に被験者を配置 し、航行中または停泊、停留中の対象船舶を昼間、 水平線が視認できる環境で目視観測し、被験者の距 離感を計測した。距離感に対して心理的な影響を排 除するために、被験者は船船の運航に携わっている が当直中でない者を対象とした。また、実験開始前 に被験者に今までの経験と直接視覚から得られた情 報だけから船舶に対する距離を感覚的に答えて欲し い旨を説明し、直前に被験者に対して実験に用いる 他の船舶までの距離を含む如何なる情報をも教示お よび学習させてはいない。被験者に対象船舶の事前 情報を与えないよう、実験者は対象船舶をランダム に選択し実験直前に力位を指示する。そこで、被験 者は指示された方位に存在する船舶を視覚により知 覚し、その後船舶までの距離を調查シートに各自筆 記した。なお、方位測定にレピータコンパス、遠方 確認のために双眼鏡の使用は許可した。また、対象 船舶までの真の距離はARPAから得られた情報を 
用いた。

\section{2 .2 シミュレータ実験}

シミュレータによる実験は距離情報の教示を行わ ない実験と、あらかじめ距離情報の教示を行う 2 種 類の実験とした。距離情報の教示を行わない実験は、 水平線だけが視認できる海域に自船を設置し、距離 0.2 海里から 4.0 海里の間に 0.2 海里間隔でそれぞれ 相対方位、アスペクト、船種が異なる対象船舶を 1 隻のみ距離、相対方位、アスペクト、船種をランダ ムに変えて表示する。被験者は視覚により対象船舶 を知覚した後にその船までの距離を口頭で答え、そ れを実験補助者が筆記した。実験における眼高は本 学練習船「深江丸」と航海訓練所練習汽船を対象と して6.5mおうよび $15.0 \mathrm{~m} の 2$ 種類とした。また、被験 者にはあらかじめ距離感の計測に影響を与えると考 えられる情報は与えていない。一回の実験では、一 人の被験者に対し20隻の船舶とした。

次にあらかじめ距離情報の教示を行った実験で は、ほぼ正船首 5.0 海里から自船の右舷 0.2 海里を反 航通過する全長約 $200 \mathrm{~m} の$ 自動車専用船を接近させ、 被験者が距離情報を必要とする時にARPAにより 距離情報を与えた。その後、距離の教示を行わない 実験と全く同実験を行った。

\section{4 . 結果と考察}

ここでは実験から得られた結果と考察を述べる。 全ての実験結果において、被験者が対象船舶に対し て知覚、認知後に解答した距離を「認知距離」、各実 験でARPAから得られた距離情報を「物理距離」と し、計測上の誤差を無視し真の距離に限りなく近い 值を示していると見なす。また認知距離の誤差の程 度を表す指標として、各認知距離から物理距離を引 いた值（認知距離誤差）をそれぞれの物理距離で割 ることで距離に対する正規化を行った結果を「距離 愦差率」と呼ぶ。

\section{1 海上実験結果}

深江丸船橋に打ける海上実験の結果を表 3 に、ま た一例として航海士経験のある被験者 $\mathrm{B}$ と未経験の 被験者 $\mathrm{D} 、 2$ 名の各物理距離における認知距離の結 果を図 1 に示す。表 3 から被験者毎に見ると航海士 経験の有無で距離誤差率の正負が分かれており、経 験者は物理距離 (真值)よりも距離を近めに判断し、 未経験者は遠めに判断する傾向が見られるものの、 海上での認知距離は各被験者ともかなり正確である と言える。

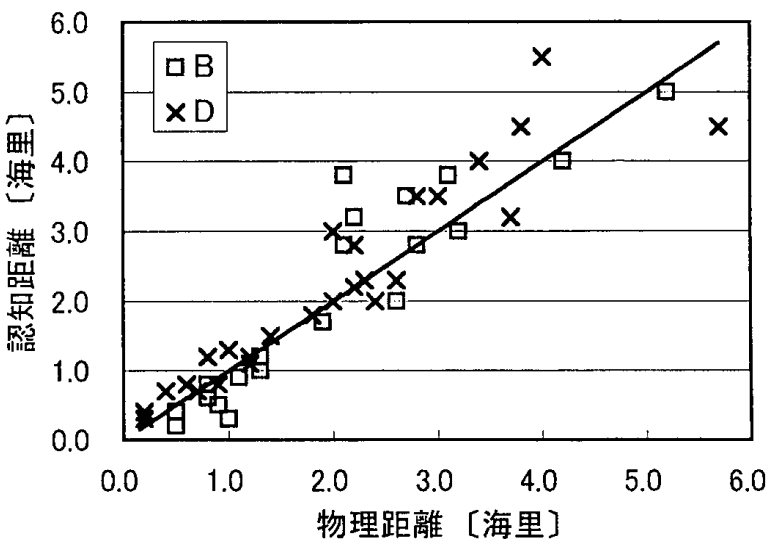

図 1 海上実験結果の一例

\section{2 シミュレータ実験結果}

\section{2 .1 教示を行わない実験}

教示を行わないシミュレータ実験は眼高 $6.5 \mathrm{~m}$ と $15.0 \mathrm{~m} て ゙$ 行ったが、その実験における被験者の乗船 経験、距離誤差率平均および標準偏差を表 4 に示す。 被験者は全部で 5 名、その内 3 名は航海士経験者で、 残り 2 名は乗組員である。

眼高 $6.5 \mathrm{~m}$ における実験は通常乗船している船舶 と同じ眼高に設定していることから、海上での経験 および記憶に基づいた結果である。表 4 から航海士 の経験年数が長い被験者ほど、正確な距離感を示し ていることがわかる。航海士経験者は、今までの乗 船経験およびその記憶に基づいて正確な距離感を有 している。その理由の一つには自分の眼高における 水平線と対象船舶の喫水線間の俯角による距離の認 知がかなり正確に働いているためと考えられ る(15)。また、航海士経験のない被験者は距離を遠く に判断する傾向を示している。さらに、距離誤差率 と物理距離の関係を被験者每に図 2 に示す。この結 果から、航海士経験のある被験者F、G、Cは、物理 距離0.4海里から 4.0 海里までの間の距離誤差率の平 均がー0.5から+0.5の範囲に分布しているのに対 し、航海士経験のない被験者 $\mathrm{D} 、 \mathrm{E}$ は物理距離が小さ くなるに従い大きな距離誤差率を示している。四 3 は被験者全員の距離誤差率平均と標準偏差を示した ものであるが、同図から物理距離 2.0 海里以上で距離 誤差率がほぼー0.5から＋0.5の範囲内でありほぼ正 確な距離感であることを示しているが、2.0海里以下 になると距離誤差率の平均および標準偏差ともに大 きくなっている。そこで、眼高 $6.5 \mathrm{~m}$ 程度の船舶にお いて 2.0 海里付近に他の船舶に関する情報収集にお ける境界が存在するようにも考之られる。

眼高 $15.0 \mathrm{~m}$ におけるシミュレータ実験では眼高 6. $5 \mathrm{~m}$ のシミュレータ実験と同じ被験者であるため、眼 


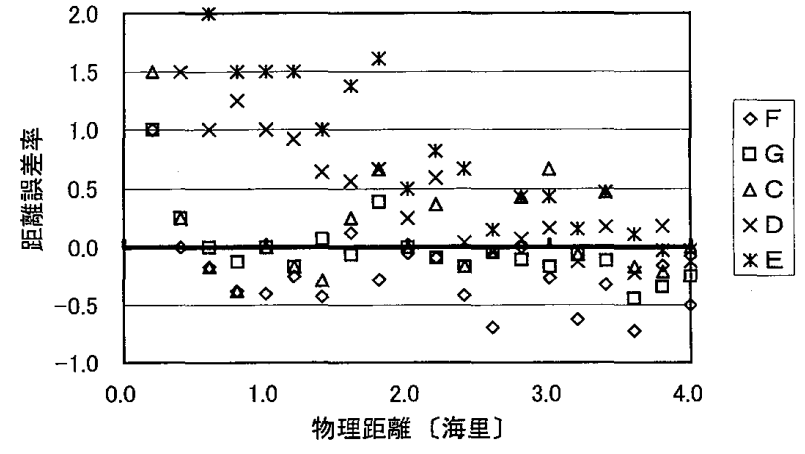

図 2 シミュレー夕実験〔眼高 $6.5 \mathrm{~m}$ における 距離誤差率（被験者ごと）

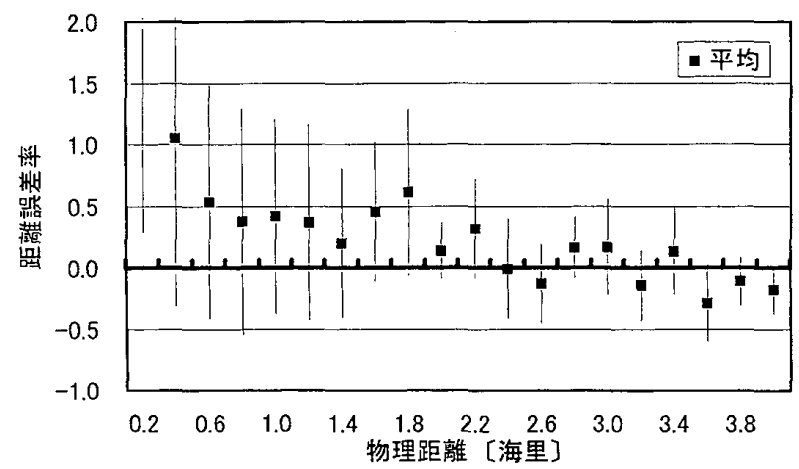

図 3 シミュレー夕実験〔眼高 $6.5 \mathrm{~m}$ における 距離誤差率 (平均、標準偏差)

高 $15.0 \mathrm{~m}$ に対する認知距離を経験的に記憶している とは考えられない。表 4 から眼高 $6.5 \mathrm{~m} の$ 結果と比較 して、航海士経験者の距離誤差率の標準偏差はあま り変化がないが平均は幾分大きくなり、距離感が多 少不正確になっていることがわかる。一方、未経験 者は距離誤差率の標準偏差はあまり変化がないが平 均は逆に小さくなっており、眼高 $6.5 \mathrm{~m}$ の結果に比べ 正確な距離感を示している。

表 $3 、 4$ (眼高 $6.5 \mathrm{~m}$ 参照) から海上とシミュレー 夕実験の結果を比較すると、航海士経験者は海上お よびシミュレータにおける距離判断に平均、標準偏 差ともに大きな違いは見受けられないが、未経験者
は海上実験の結果に比べてシミュレータ実験の結果 は距離䛊差率の平均および標準偏差ともに大きな数 值を示しており、経験者と未経験者を同様にシミュ レータを用いて訓練することには自ずと違いが出る 可能性を示している。また、経験者および未経験者 ともに通常経験している海上ではかなり正確な距離 感を示しているが、シミュレータでは若干ではある が距離を遠めに判断する傾向が見られる。

\subsection{2 教示による学習効果}

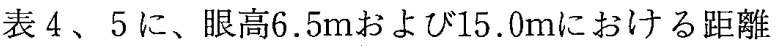
の教示後のシミュレータ実験の結果を示す。眼高6. $5 \mathrm{~m}$ の結果から航海士経験の長い3名の被験者は教示 前と教示後の結果に大きな変化は見られないが、航 海士経験のない 2 名の被験者は教示前に比べ、距離 誤差率平均および標準偏差が共に小さくなり、より 正確な距離感に近づいたことを示している。このこ とから認知距離に対する教示の効果は航海士経験の 少ない、または距離を正確に判断できない被訓練者 に対して大きな効果があるといえる。

また、表 5 に示した眼高 $15.0 \mathrm{~m}$ における教示後の 実験結果から、全ての被験者で距離感に対する情報 がない教示前に此べ、教示後には距離詥差率平均お よび標準偏差共に小さくなり、教示前に比べより正 確な距離を示していることがわかる。

\subsection{3 眼高の違いによる認知距離}

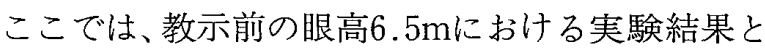
眼高 $15.0 \mathrm{~m}$ の結果を比較し、眼高が異なることで距 離感にどのような影響を与えているかを考察する。 各眼高における実験結果を比較すると、一部の被験 者を除き眼高 $6.5 \mathrm{~m}$ における距離誤差率平均よりも 眼高 $15.0 \mathrm{~m}$ にける距離誤差率平均は小さな值を示 している。被験者の位置から同じ距離にある対象船 舶であっても被験者の眼高が高くなることで、水平 線と対象船船の契水線のなす俯角だけが大きくなっ ている。しかし、各被験者が経験および記憶してい る水平線と喫水線間の俯角と対象船舶までの距離と

表 3 眼高 $6.5 \mathrm{~m}$ 海上実験結果

\begin{tabular}{|c||c|c|c|c|c|}
\hline \multirow{2}{*}{ 被験者 } & デー夕数 & 航海士経験 & 乗船経験 & \multicolumn{2}{|c|}{ 距離誤差率 } \\
\cline { 5 - 6 } & & & & 平均值 & 標準偏差 \\
\hline $\mathrm{A}$ & 11 & 40 [年] & 40 [年] & -0.15 & 0.27 \\
\hline $\mathrm{B}$ & 22 & $8[$ 年] & 8 [年] & -0.05 & 0.34 \\
\hline $\mathrm{C}$ & 37 & 4 [月] & 27 [年] & -0.05 & 0.33 \\
\hline $\mathrm{D}$ & 26 & - & 19 [年] & 0.18 & 0.30 \\
\hline $\mathrm{E}$ & 19 & - & 4 [月] & 0.07 & 0.35 \\
\hline
\end{tabular}




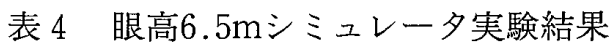

\begin{tabular}{|c|c|c|c|c|c|c|c|}
\hline \multirow[t]{2}{*}{ 被験者 } & \multirow[t]{2}{*}{ テータ数 } & \multirow[t]{2}{*}{ 航海士経験 } & \multirow[t]{2}{*}{ 乗船経験 } & \multicolumn{2}{|c|}{ 教示前の距離誤差率 } & \multicolumn{2}{|c|}{ 教示後の距離誤差率 } \\
\hline & & & & 平均值 & 標準偏差 & 平均値 & 標準偏差 \\
\hline $\mathrm{F}$ & 20 & 15 [年] & $15[$ 年 $]$ & -0.23 & 0.37 & -0.03 & 0.32 \\
\hline $\mathrm{G}$ & 20 & 6 [年] & $6[$ 年 $]$ & -0.02 & 0.30 & -0.03 & 0.24 \\
\hline $\mathrm{C}$ & 20 & 4 [月] & $27[$ 年] & 0.15 & 0.44 & 0.37 & 0.52 \\
\hline $\mathrm{D}$ & 20 & - & 19[年] & 0.58 & 0.75 & 0.42 & 0.53 \\
\hline $\mathrm{E}$ & 20 & - & 4 [月] & 1.20 & 1.49 & 0.69 & 0.96 \\
\hline
\end{tabular}

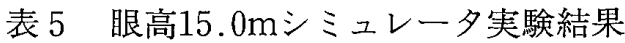

\begin{tabular}{|c|c|c|c|c|c|c|c|}
\hline \multirow[t]{2}{*}{ 被験者 } & \multirow[t]{2}{*}{ データ数 } & \multirow[t]{2}{*}{ 航海士経験 } & \multirow[t]{2}{*}{ 乗船経験 } & \multicolumn{2}{|c|}{ 教示前の距離誤差率 } & \multicolumn{2}{|c|}{ 教示後の距離誤差率 } \\
\hline & & & & 平均值 & 標準偏差 & 平均値 & 標準偏差 \\
\hline$F$ & 20 & $15[$ 年] & $15[$ 年 $]$ & -0.46 & 0.28 & -0.16 & 0.23 \\
\hline G & 20 & $6[$ 年] & $6[$ 年 $]$ & 0.64 & 0.38 & -0.21 & 0.26 \\
\hline $\mathrm{C}$ & 20 & 4[月] & $27[$ 年] & 0.17 & 0.61 & 0.12 & 0.53 \\
\hline $\mathrm{D}$ & 20 & - & 19 [年] & 0.17 & 0.47 & -0.11 & 0.27 \\
\hline $\mathrm{E}$ & 20 & - & 4[月] & 1.10 & 0.94 & 0.40 & 0.52 \\
\hline
\end{tabular}

の関係は眼高が $6.5 \mathrm{~m}$ のままであることから、俯角だ けを大きくすることで被験者は物理距離よりも対象 船舶までの距離を近く判断していると考えられる。 このことは、単眼性の距離判断の手掛かりとして水 平線と対象船舶の契水線のなす俯角が大きな役割を 果たしている可能性が高いと考えられる。

そこで通常眼高 $15.0 \mathrm{~m}$ の船舶の航海士を被験者と し、シミュレータで設定した眼高 $6.5 \mathrm{~m}$ の船舶の船橋 から対象船舶の視覚による距離感を求める実験結果 を図 4 に示す。その結果、1.0海里以下では物理距離 に近い距離感を示すが、物理距離が大きくなるにつ れ距離を遠めに判断する傾向がある。この傾向を定 量的に示すために以下の式を用いて、認知距離を異 なる眼高における距離に変換、この距離を「変換距 離」と定義する。これは、本来 $15.0 \mathrm{~m}$ の眼高の船舶に 乗船している操船者がそれと異なる眼高 $6.5 \mathrm{~m}$ の船 船に乗船した当初に、これらの眼高の違いがどの程 度対象船舶までの認知距離に影響を及ぼすかを示す 簡略式である。

$$
\begin{gathered}
D=\frac{H}{1852.0 \times \tan \theta} \\
\theta=\tan ^{-1}\left(\frac{h \times 1852.0}{d}\right)
\end{gathered}
$$

ここで、Dは変換距離 $[$ 海里］、时俯角 $[\mathrm{deg}] 、 \mathrm{H}$ は眼高 $(=6.5[\mathrm{~m}]) 、 \mathrm{~h}$ 眼高 $(=15.0[\mathrm{~m}]) 、 \mathrm{~d}$
認知距離 [海里]、とする。

図 4 の中に、上式を用いて眼高の違いによる認知 距離に変換を行った結果を“ $\square ” て ゙$ 示す。その結果、

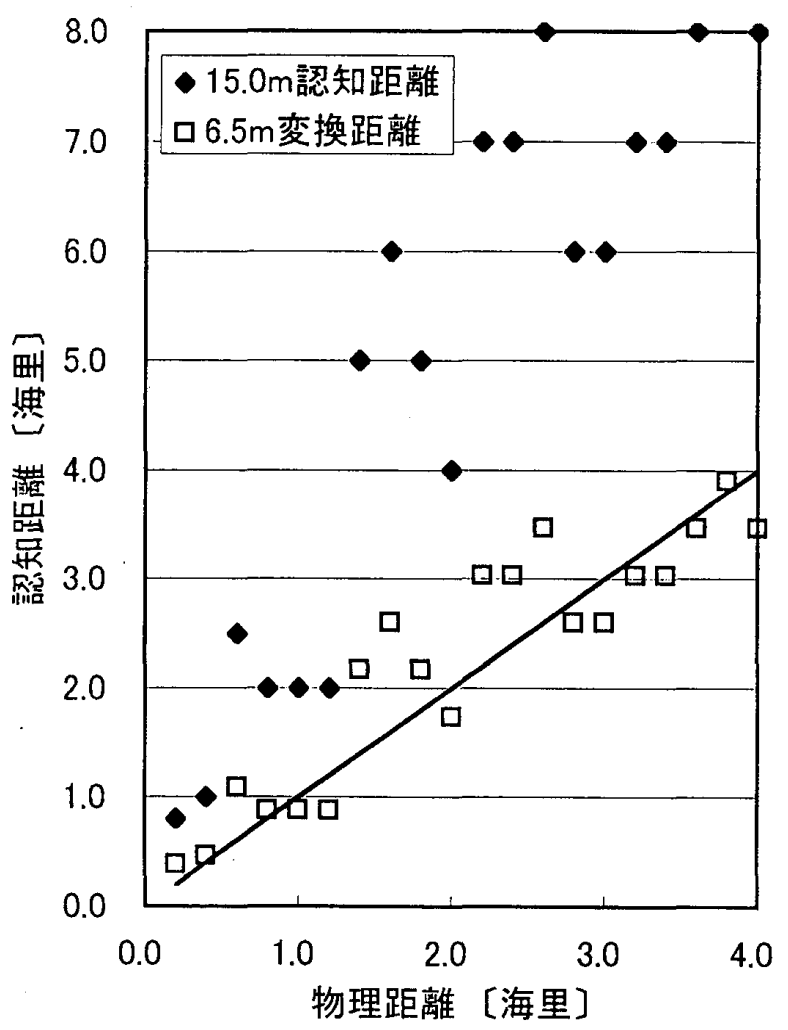

図 4 眼高の違いによる認知距離 （眼高数值情報なし） 
物理距離と認知距離との誤差が非常に小さくなり、 変換距離は物理距離に近い結果を示している。この ことから、航海士経験者は眼高に応じた水平線と対 象船舶の揳水線までの俯角と、その船舶までの距離 の関係を比較的正確に経験、記憶しているため、眼 高が異なっているにもかかわらず、以前の経験と記 憶によって得られた認知距離から正確ではない結果 を示したと考えられる。

さらに、被験者に眼高の数值情報を与えることで 認知距離がどの程度変化するかを調べるために、眼 高15.0mの船舶に通常乗船している航海士に「眼高

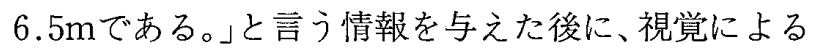
認知距離に対する実験を行った（ただし、この被験 者は図 4 の被験者とは異なる。)。この結果を図 5 に 示す。眼高の数值情報を与えることで、被験者は水 平線までの視認距離が約 5 海里であることを意識す る。そこで、図 5 から水平線と哭水線までの俯角が 大きい2.0海里以下では、経験と記憶から得られる認 知距離が強いためか変換距離はほぼ正確な值を示し ている。しかしながら、船舶の䙵水線と水平線が接 近する遠距離では最大で約6海里の認知距離を示し ており、水平線までの距離を意識することによる飽 和現象が見受けられる。一方眼高情報を与之なかっ た被験者の場合、最大約 8 海里までの認知距離を示 していることから、眼高の数值情報によって被験者 は水平線までの視認距離を意識し認知距離に飽和現 象を生じさせたものと考えられる。

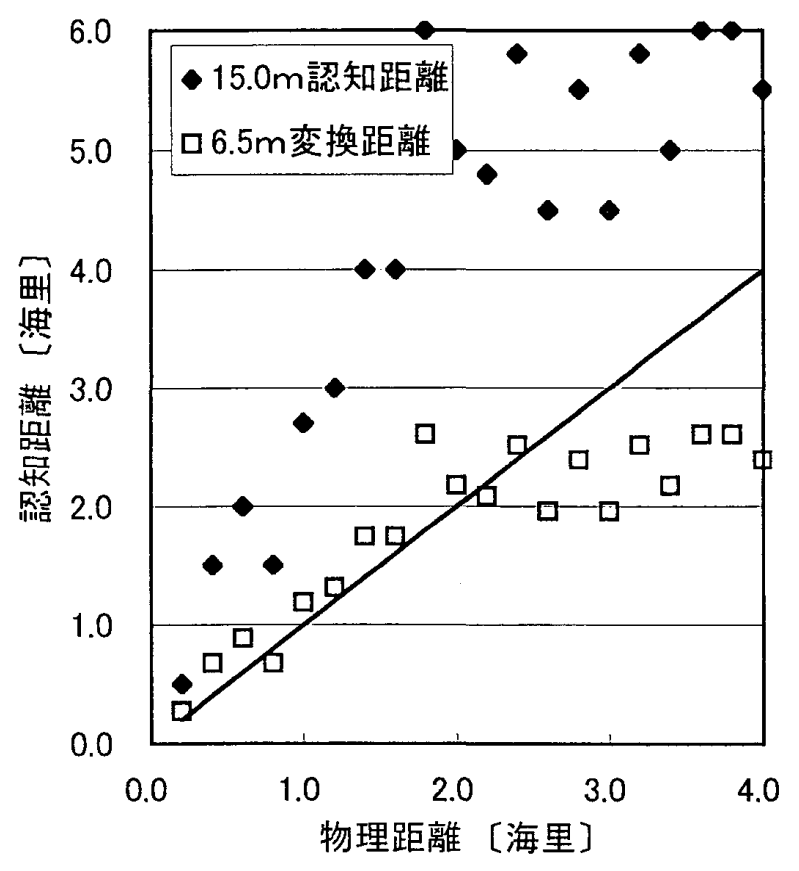

図 5 眼高の違いによる認知距離 (眼高数值情報有り)

\section{5.まとめ}

本研究から得られた結果をまとめると以下のこと が言える。

1. 眼高が変化しない場合、航海士経験者は、シ ミュレータにおいても海上と同等の距離感を 有して扔り、比較的スムーズにシミュレータ 実習に移行することが出来る。

2. 眼高が変化した直後の認知距離は不正確にな クやすく、眼高の数值情報があっても経験、 記憶している距離感の影響を大きく受ける。 また、距離感には水平線と他船の契水線とが なす俯角が大きく影響している。

3.シミュレータに㧍ける距離感を正確なものに するためには、距離に対する教示が有効であ る。

4. 職種（航海士、乗組員、学生）による立場や 責任感の違いが認知過程で距離感に影響を及 ぼすと考えられる。このことから、経験の少 ない被験者の距離感は眼高 $6.5 \mathrm{~m}$ の時 2.0 海里 以下の船舶を実際よりも遠く認知する傾向が ある。

5 . 航海士経験者の距離感は、眼高 $6.5 \mathrm{~m}$ の時 2.0 海里以下にある船舶を実際の距離よりも近く 認知する傾向がある。

これらのことから学生のように、経験の少ない訓 練生を対象としたシミュレー夕訓練では、事前に正 確な距離や必要な情報を教示する必要があり、近距 離にある船舶を遠くに判断する可能性があることを 理解した上で、訓練を実施する必要がある。

これは海上でもいえることであり、経験が浅いま たは眼高が変化した場合などは、レーダを使用し、 早期に正確な距離や必要な情報を教示、入手するこ とが、安全に船舶を運航するために必要である。

\section{謝 辞}

今回の研究を行うに当たり、本学練習船媣江丸乗 組員、航海計器学研究室清水谷龍大学院生、米川和 秀学生、小林真学生、横山聡学生、海技大学校南屋 太郎氏に御協力を頂いた事に、深く感謝するととも に、謝意を表する。

\section{参 考 文 献}

（1）新井康夫他4名：海技の体系化に基づく操船シ ミュレータ訓練システムの開発, 日本航海学会, 第 102 号, pp. 279 289, 平成12年 3 月.

（2）小林弘明他3名：海技の習熟特性に基づく必要 
訓練時間の研究, 日本航海学会, 第 102 号, $p p$. $291 \sim 300$, 平成 12 年 3 月.

（3）中村紳也他3名：操船シミュレータの開発と安 全評価研究 (訓練) への適用に関する考察, 日本 航海学会, 第86号, pp. $261 \sim 269$, 平成 4 年 3 月.

（4）長畑司: 避航の判断と操船者の特性, 日本航海 学会論文集, 第 48 号, pp.77 85, 昭和 47 年12月.

（5）長畑司：避行の判断と操船者の特性－III, 日本 航海学会論文集, 第63号, pp. $19 \sim 28$, 昭和 55 年 8 月.

（6）遠藤真・山崎祐介：避航操船における操船者の 取得する視覚情報について，日本航海学会論文 集，第86号，pp. $29 \sim 37$, 平成 4 年 3 月.

（7）黑川久幸・鶴田三郎：見張りプロセスのモデル 化, 日本航海学会論文集, 第86号, pp.39 48, 平成 4 年 3 月.

（8）小林弘明 - 内野明子：操船情報と人間特性, 日 本航海学会論文集, 第91号, pp.255 261, 平成 6 年 9 月.

（9）黒川肇・今津隼馬：他船視覚情報の収集自動化 に関する研究，日本航海学会論文集，第 82 号， pp. 85 91, 平成 2 年 3 月.

(10) 樋渡涓二：視聴覚情報概論, 朝倉出版, pp. $3 \sim 14$, 昭和 62 年 7 月.

（11）葉原耕平他：視聴覚情報科学, オ一ム社, pp. $1 \sim 3$, pp. $116 \sim 123$, 平成 6 年 9 月.

(12) 箱田裕司：認知科学のフロンティア，サイエ ンス社, $\mathrm{pp} .21 \sim 25$, 平成 4 年 5 月.

(13) 淀川英司他：視聴覚の認知科学, 社団法人電子 情報通信学会, pp. 25 , 平成10年3月。

(14) 原田政美：目のはたらきと学習障害児教育と学
校保健の基礎知識, 慶應通信, pp.160 178, 平 成元年 1 月.

（15）林祐司：他船実画像からの航行情報抽出方法に ついての研究, 航海, 第107号, pp.80 88, 平 成 3 年 3 月。

\section{質 疑 応 答}

嶋田博行 (神戸商船大学)：

（1）距離判断を行うには、距離以外の要因をどの ように統制されているのでしょうか。

（2）また直接距離をシートに書かれていますが、 判断の基準に刺激の系列が影響するので、そのあ たりはどのように考慮されているのでしょうか。

（3）さらに誤差については、距離とリニアに増加 するのでしょうか。例えば短い距離では過大評価、 長い距離では過小評価されるのでしょうか。

\section{馬谷正樹：}

（1）海上実験においては、海域の状況から陸岸や 害験対象以外の船舶などの比較対象物が存在する 場合もありますが、シミュレー夕実験では視野内 に対象船舶は1隻のみで、船首部映像も非表示とし て比較対象物の統制は行っております。

（2）影響がないよう実験開始前、被験者に対して 経験と視覚情報から得た感覚的な距離を記入する ことを説明しています。また同一の対象船舶を同 時に複数の被験者が観測したため、各被験者が直 接シートに記入する方法をとりました。

(3) 䛊差については結果にもありますように、航 海士未経験者は短い距離で過大評価、航海士経験 者は短い距離で過小評価し、経験の差で大きく結 果が異なっております。 